\title{
A case for establishment of the Ferrous Materials Development Network (FMDN) in South Africa
}

\author{
M Phasha ${ }^{\text {a*, J Moema }}{ }^{b}$, J Papoc \\ Mintek, 200 Malibongwe Dr, Praegville, Randburg, 2194, Johannesburg, South Africa \\ Email:aMajeP@mintek.co.za, bJosephM@mintek.co.za, cJonesP@mintek.co.za
}

\begin{abstract}
South Africa is known to be one of the mineral endowed countries in the world, bearing large quantities of iron, chrome, manganese and vanadium reserves that are key to iron and steel industries. It is thus vital to leverage on this natural resource endowment to build a dynamic industrial economy capable of creating sustainable jobs. Central to achieving this goal is the need to derive greater economic value from these natural resources, which will reduce import levels and create export opportunities. Currently, however, the local iron and steel industry is forced to navigate some of the known challenges such as the cost of energy, transportation, labour and steel, in order to remain competitive and operational. These matters which hamper the realization of beneficiation aspirations do not only have a huge impact on the downstream value-adding steel industry but also make the cost of doing business in SA unattractive.

Consequently, based on its capability, relevancy and experience in supporting the iron and steel sector for many years, Mintek has been entrusted with the responsibility to host the Ferrous Materials Development Network (FMDN) by government through advanced materials initiative (AMI) programme to coordinate research on ferrous materials in the country.

The purpose of this paper is to illustrate the need for interdependent research activities in ferrous materials in South Africa, which is underpinned by collaborative research, development and innovation (RDI) efforts between science councils, academia and industry. These activities are aimed at generating local know how, fostering local and international collaboration, development of human capital (HCD), supporting job creation through beneficiation, identification of relevant advanced technologies to improve competitiveness, localization of designated castings, design and development of new ferrous materials with enhanced properties to enable access to niche export markets as well as improving local capability to produce high-end ferrous products for critical sectors of the economy such as petrochemical, energy generation, transportation, mining, etc.
\end{abstract}

Keywords: Metal ores, ferrous metals, beneficiation; localization, design and development, advanced ferrous materials

\section{Background}

\subsection{Metallurgy of iron and steel making processes}

Iron and steel constitute about $90 \%$ of the total metal consumed globally in various applications, on tonnage basis, which renders this industry sector a major component of manufacturing industry. The main areas of application are construction, manufacture of transportation vehicles, machinery, pipes and tanks in energy sector, pumps and valves in water sector as well cans and containers for packaging sector. Key pillar behind the success of iron and steel industry is the deliberate and strategic alignment between upstream (primary processes) and downstream (secondary and tertiary processes) manufacturing segments, as both are vital to natural resource beneficiation aspirations from which dynamic industrial economy thrives. In this paper, the South African beneficiation process for ferrous resources is divided into 4 stages. The first stage involves explorations and processing of ores which occur at the mining sites. The metallurgical value-add process involving iron and steel making activities takes place in the second stage. The stage at which the manufacturing for downstream begins at the mills is the third stage, wherein shaping and coating of steel into intermediate products is carried out. Lastly, stage four which is often called manufacturing by fabrication, is where most common beneficiation outside the mills typically occurs.

Besides acquiring mining rights and the subsequent mining exploration activities, the most energy and capital intensive processes are in the second stage of the value-add chain, where iron and steel are produced. The first metallurgical ore beneficiation step is the iron making process which involves iron ore reduction. Like in many countries across the world, the most popular blast furnaces (BF) shown in Figure 1(a) which accounts for over $90 \%$ of iron producing methods is used in SA, even though there are several other processes such as direct or smelting reduction (DR/SR) deployed elsewhere. The iron making process in BF is a heat and mass transfer process in which the furnace is divided into different zones as determined by the chemical and physical state of the feed and temperature. The main difference between the methods above is that a mixture of agglomerated iron, limestone $\left(\mathrm{CaCO}_{3}\right)$ or dolomite $\left(\mathrm{CaMg}\left(\mathrm{CO}_{3}\right)_{2}\right)$, silica $\left(\mathrm{SiO}_{2}\right)$ and metallurgical coke is placed in a blast furnace. Heated air is then blown into the furnace and causes a reaction between $\left.\mathrm{CaCO}_{3}\right)$ or $\left.\mathrm{CaMg}\left(\mathrm{CO}_{3}\right)_{2}\right)$ and silica $\left(\mathrm{SiO}_{2}\right)$ to form a molten slag, which is separated from molten iron commonly known as pig iron as an input material in the steel making furnace called basic oxygen furnace (BOF) shown in Figure 1(b). On the other hand, the reduction of iron ore in the DR process occurs in 


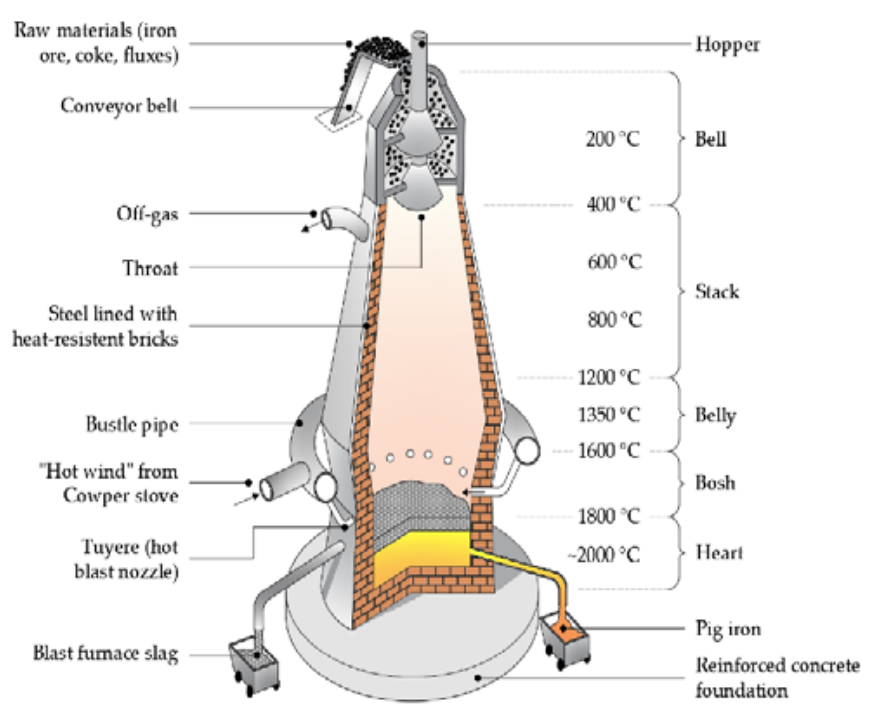

(a) $\mathrm{BF}$

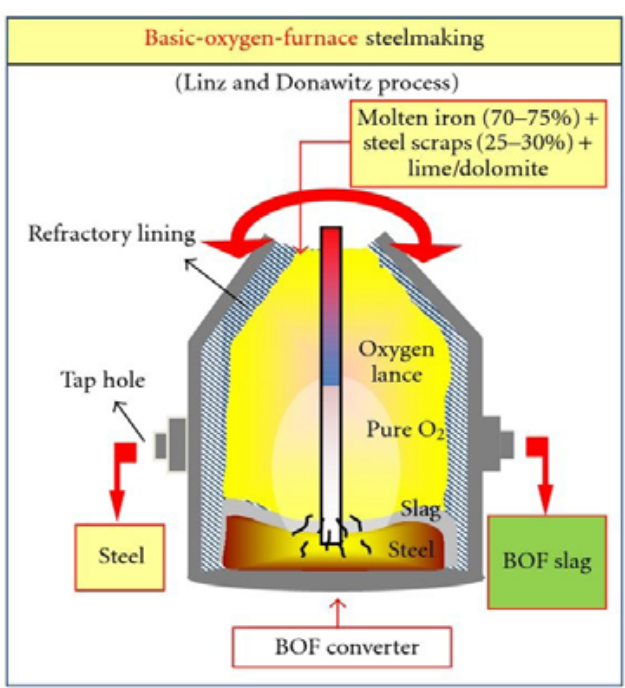

(b) $\mathrm{BOF}$

Figure 1: Schematic diagrams of typical furnaces used in Iron and Steel making processes ${ }^{1}$

a solid-state as opposed to molten state using non-coking coal or gaseous reducing agents in the place of metallurgical coke derived from high grade coals. Although both processes use the iron ore as the principal raw material, the latter often bring significant levels of undesired impurities such as sulphur $(\mathrm{S})$ and phosphorus $(\mathrm{P})$ whose presence results in brittle and weak steel products.

The second metallurgical beneficiation step is the steel making process which is a continuation from the end of the first step. The main role of this process is to convert pig iron, scrap or iron from DR process or their mixture into steel though use of BOF, in which the refining process that removes $\mathrm{S}$ and $\mathrm{P}$ impurities and reduces the carbon and silicon content occurs. The most popular steel production methods are BOF and EAF (electric arc furnace) which is usually regarded as the secondary production process, and least popular is the open hearth furnace (OHF), at least in most countries. In BOF steel making process, the molten iron produced from $\mathrm{BF}$ is charged into BOF via ladles and a jet of pure oxygen is injected from the top of the furnace. Once blown-in, the oxygen reacts with carbon and other unwanted impurities to form oxides which can then be skimmed-off and thus leading to a much cleaner and more valuable material called steel. The latter can be alloyed with elements of choice to obtain desired microstructural and mechanical properties required in the final product for specific industrial applications, as summarized in Figure 2.

\subsection{State of SA steel industry}

South Africa (SA) is known to be one of the mineral-rich countries in the world. Besides coal, precious group metals (PGMs) and other

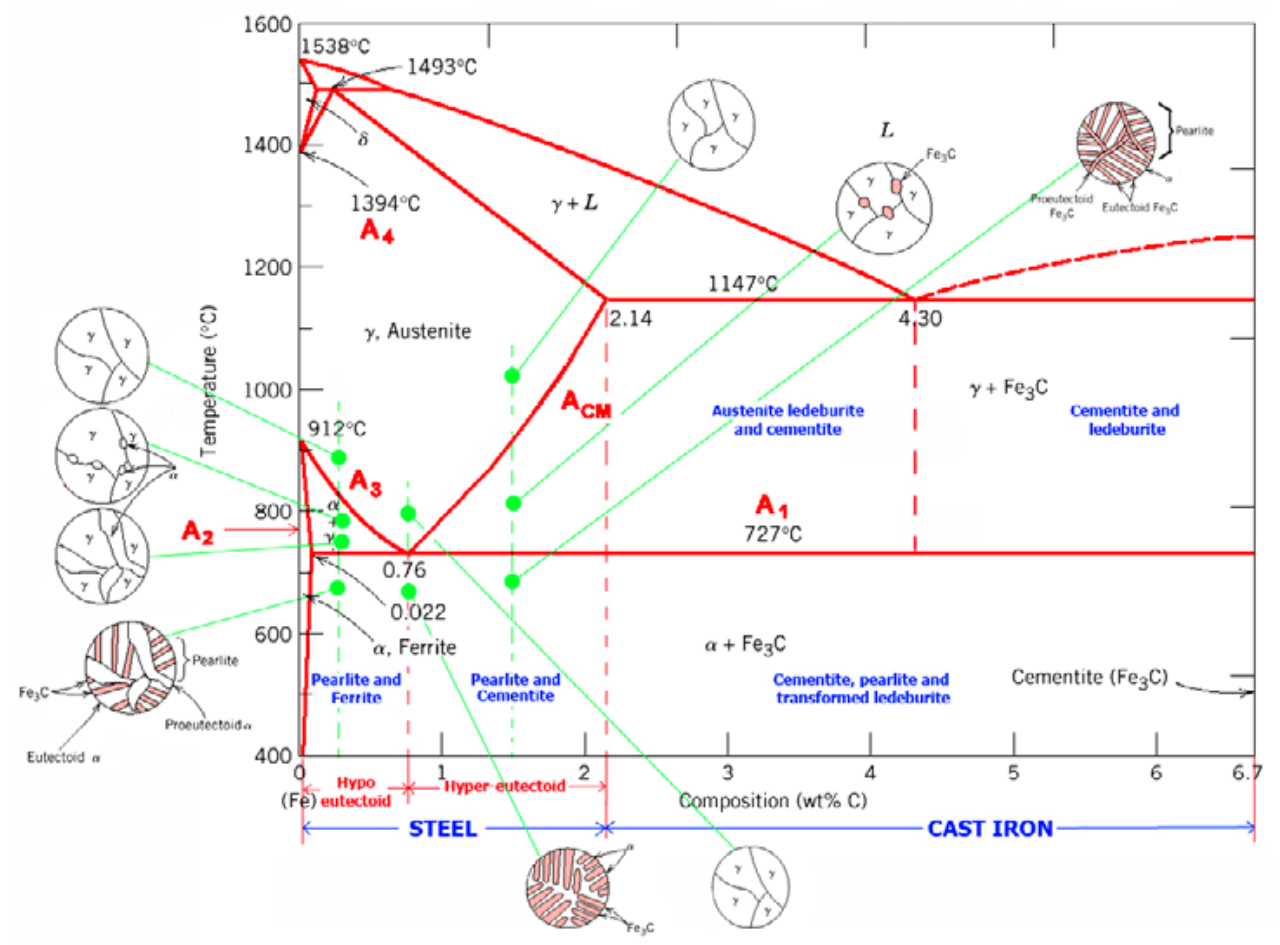

Figure 2: Typical Fe-C phase diagram 
mined commodities, SA endows massive reserves of iron $(\mathrm{Fe})$, chrome $(\mathrm{Cr})$, manganese $(\mathrm{Mn})$ and vanadium $(\mathrm{V})$ metals which are key to iron and steel industries in the form ores. These mineral ores are distributed mostly towards north-western part of the country, as shown in Figure 3. It is generally acknowledged that central to natural resource endowment is the need and capacity for valueadd, behind which a dynamic industrial economy is built, resulting in the creation of sustainable jobs and meaningful contribution to the country's gross domestic product (GDP). Further benefits of deriving greater economic value are reduced import levels and higher export opportunities. At present, however, the local iron and steel industry is forced to navigate some of the known challenges such as the cost of energy and its availability, transportation, labour and steel, in order to remain competitive and operational. These matters which hamper the realization of beneficiation aspirations do not only have a huge impact on the downstream value-adding steel industry but also make the cost of doing business in SA unattractive from potential international investors. For any country to successfully derive maximum economic benefits from its resources for its citizens requires a long-term strategic intent and commitment. Some of the few such countries that took a decisive and firm industrialization action are South Korea and China, with the latter becoming a dominant steel producer in the world of late.

Beside being home to principal input raw material (high grade iron ore) for iron and steel production industries, ${ }^{3}$ as well as the global steel supply being ahead of demand over the past decade, the South Africa's iron and steel industry can only accounts for less than $0.5 \%$ of the global industry. ${ }^{4}$ The combined cost of raw materials such as high grade iron ore and coking coal constitutes more than $50 \%$ of the overall production cost world-wide while the remaining cost is shared between energy, refractories, fluxes and alloys, electrodes, direct labour and overheads. ${ }^{5}$ South African's position with regards to mineral endowment and desire to grow steel industry closely resembles that of Australia. However, unlike Australia that has huge reserves of coking coal, South Africa's coking coal is mostly imported. ${ }^{6-8}$ However this situation might change due to developments in hard coking coal (HCC) project in Makhado area, ${ }^{6}$ which has the potential to provide downstream industries a competitive edge in the near future. The initiation of such project could boost the economy of Limpopo province in the short-to-medium term but would require further infrastructure investment towards establishment of Makhado-Maputo rail corridor necessary to tap into export markets. ${ }^{6-8}$ However, the timing for HCC project might be a challenge for long-term as the world is tightening legislation on curbing greenhouse-gas (GHG) emissions, which will limit the industrial use of coal in the medium-long term. Currently, the South African iron and steel industry is forced to navigate some of the challenges such as the cost of energy, transportation, labour and steel, in order to remain competitive and operational., ${ }^{910}$ These factors make the cost of doing business in SA unattractive.

Of about 55 Mt of iron ore produced in SA in 2010, only about $20 \%$ was beneficiated for local consumption while the rest was exported with minimal value-add. There are only few number of major steel manufacturers in SA based on their annual metal capacity of over 250000 tons, namely, ArcelorMittal South Africa (AMSA), Highveld Steel, former Scaw Metals, Columbus Stainless (Pty) Limited, Cape Gate (Pty) Ltd and Cape Town Iron \& Steel Works (Cisco). However, based on the relevance of their infrastructure i.e. blast furnaces (BF) only ArcelorMittal AMSA and Highveld Steel participates in the second and third stages of the ferrous beneficiation chain. The other four companies are limited to only stage three as they use scrap metal as their principal feedstock material in EAF operations.

The SA steel sector is comprised of $97 \%$ carbon-steels and 3\% stainless steels. It is reported that the steel and engineering sector

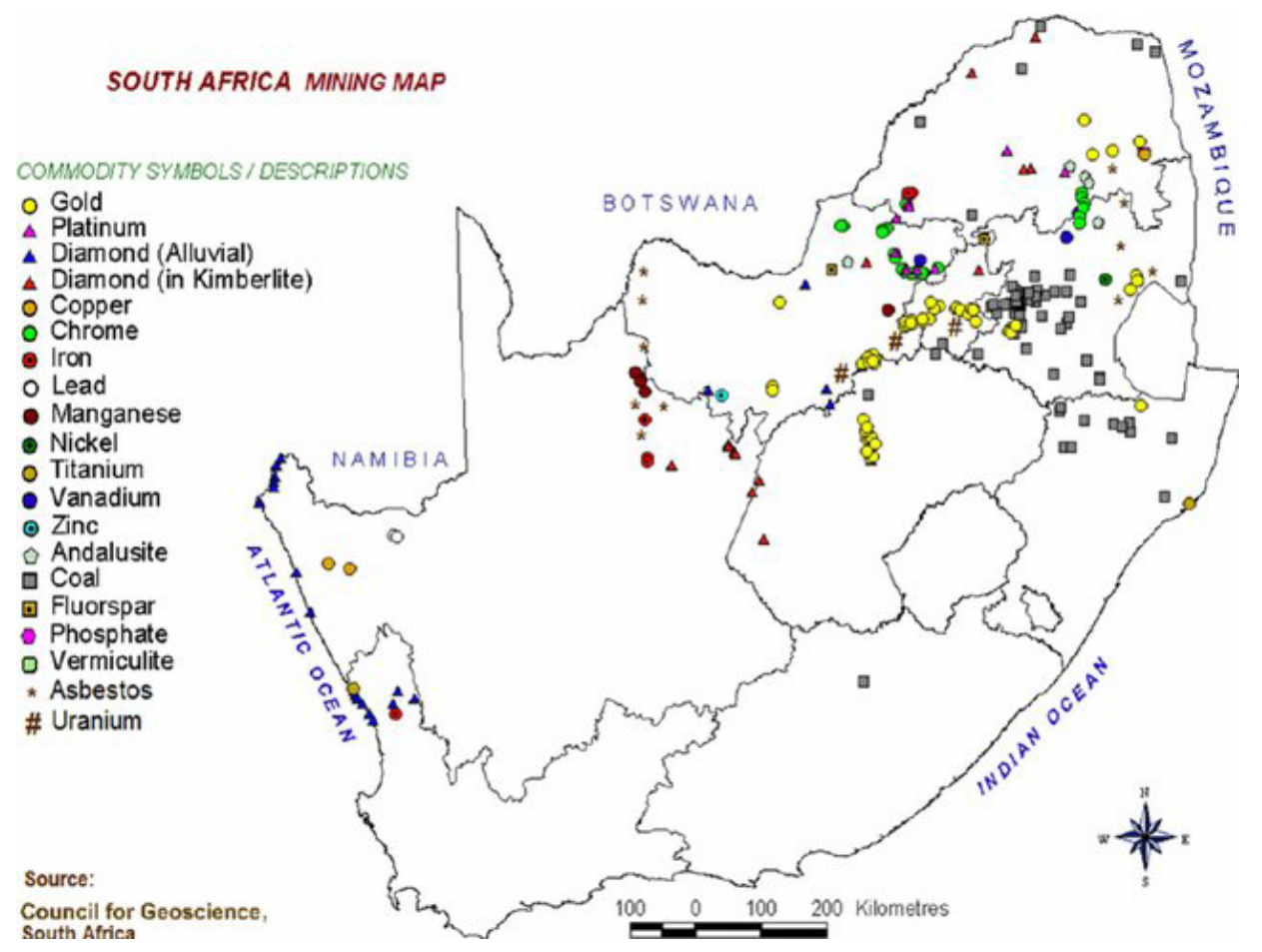

Figure 3: South African mining map. Source: Council for Geoscience, South Africa ${ }^{2}$ 


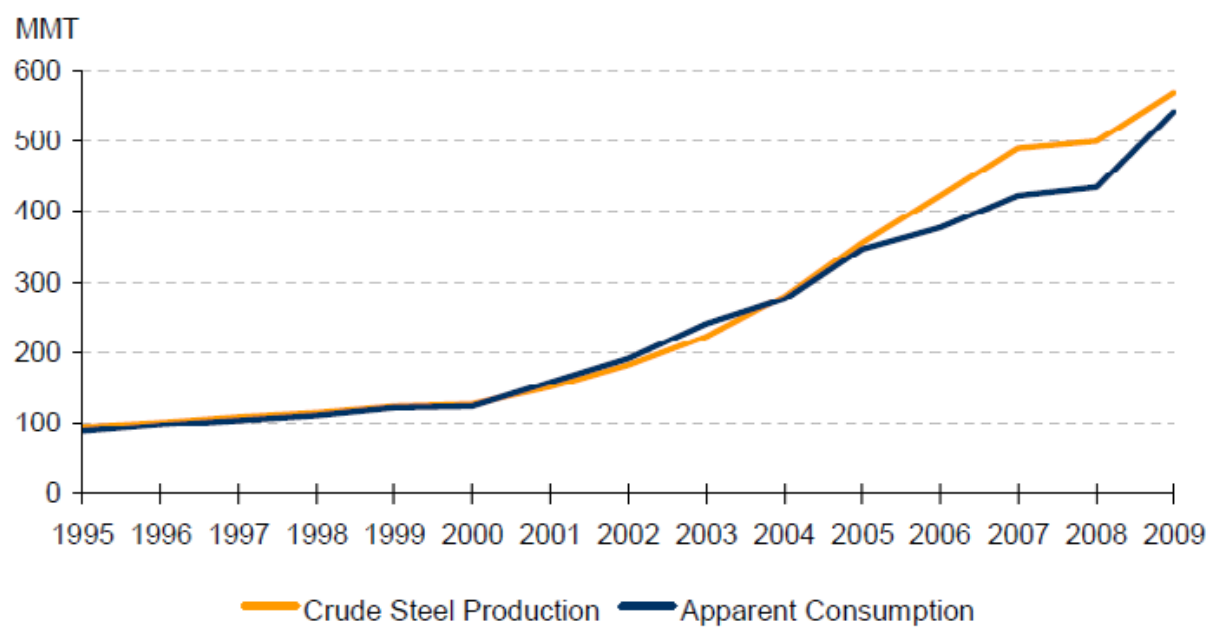

Figure 4: China's crude steel production vs local steel consumption 1995 - 2009. Sourced from World Steel in Figures: 2005, 2008, $2010 .{ }^{12}$

recorded a contribution of approximately R335 billion to SA economy in 2013 , of which $60 \%$ was from exports. ${ }^{4}$ The steel and engineering sector is a key component of manufacturing in South Africa, accounting for 190000 jobs in the direct iron-ore, steel making and fabrication industries. ${ }^{11}$ The top steel consuming industries (mining, construction, autos, cables, structural steel) contribute $\sim$ R600bn to SA's GDP $(\sim 15 \%)$ and employ $\sim 8 \mathrm{~m}$ people (direct and indirect). ${ }^{11}$ The loss of South Africa's primary steel production capacity (and becoming an exporter of iron ore and an importer of steel) will leave the country at the mercy of the global steel market in the long run and preclude it from utilizing its comparative resource endowment advantage. ${ }^{11}$ South Africa's steel industry has been in a constant decline since 2010. The sustainability and future existence of the sector as a whole (both upstream and downstream) is integral to achieve the country's economic development goals and support the growth of key sectors.

\subsection{Global view of steel production industry with reference to China and Australia}

The global demand for steel products have been increasing since the global economic downturn in 2008, mainly driven by huge investment from China and India. Currently there is a global steel making overcapacity in the excess of $400 \mathrm{Mt}$ which pose a biggest challenge in the global steel sector, particularly considering the slow global economic growth. ${ }^{11}$ The decreased demand in primary steel industry resulted in intensive price competition. Major steel producers are now looking for export opportunities with maximized beneficiation in order to absorb overcapacity.

Despite the current economic climate, and setback due to overcapacity of steel products, China must somehow be commended by developing countries for strategically deploying its competitive advantage (its large population) to drive its infrastructure development agenda about where it wanted to see itself as a country. Regardless of raised concerns regarding sustainability of its rapid increase in steel production, China has made significant strides to achieve its goal of being a developed country. China's steel industry development journey began soon after world war II during its communist era of the 1950's with what was termed
"The Great Leap Forward". ${ }^{5}$ Although it was a flop due to lack of a well thought strategy and execution plan, the desire to develop China never perished but instead it was a dream Chinese people dared to achieve. This ambitious long-term vision was based on the desire and conviction to develop China by Chinese for the people of China. Their efforts started yielding fruits almost 20 years later when the real impact on global scale was noticed in 1978, the year that marked the beginning of China's economic reform. Ever since, as shown by the graph in Figure 4, the Chinese steel production output and the consumption thereof grew rapidly hand in hand signifying that the main drive behind developing steel production capacity was more inward looking with the aim to position China as a global player based on what it can produce. ${ }^{12,13}$ Although this aggressive drive seemed unsustainable in the long-term, as it stands today, China is the world leader and a force to be reckoned with in steel production industry as shown in Figure $5,{ }^{14}$ although it relies heavily on imported key raw materials (iron ore and coal) as shown in Figure $6 .{ }^{12}$ For China to emerge from being insignificant player in the global steel industry to becoming the world's largest producer, there are principal economic factors that must be taken into consideration, namely, energy, raw materials, technology, age of the plant, location, labour in view of comparative advantage. ${ }^{5}$ In spite of its endowment advantage of key input materials in iron and steel making processes, Australia steel industry is still struggling due to other contributing factors such as high operational costs, proximity to market, and economies of scale for shipment of steel products compared to China and South Korea. Similar to China, the steel that Australia produces is actually for domestic consumption, signifying the importance of driving local demand for steel producing industry to thrive. The above observation also serves as an illustration that possession of key mineral resources alone is inadequate to provide structural advantage towards building a competitive steel industry. ${ }^{7}$

In contrast to China's competitive edge of low labour cost, high productivity and domestic steel demand, South Korea's industrialization strategy was focused on improved workforce skill levels through education, low labour cost, productivity, close proximity to market, shipbuilding development programme to 


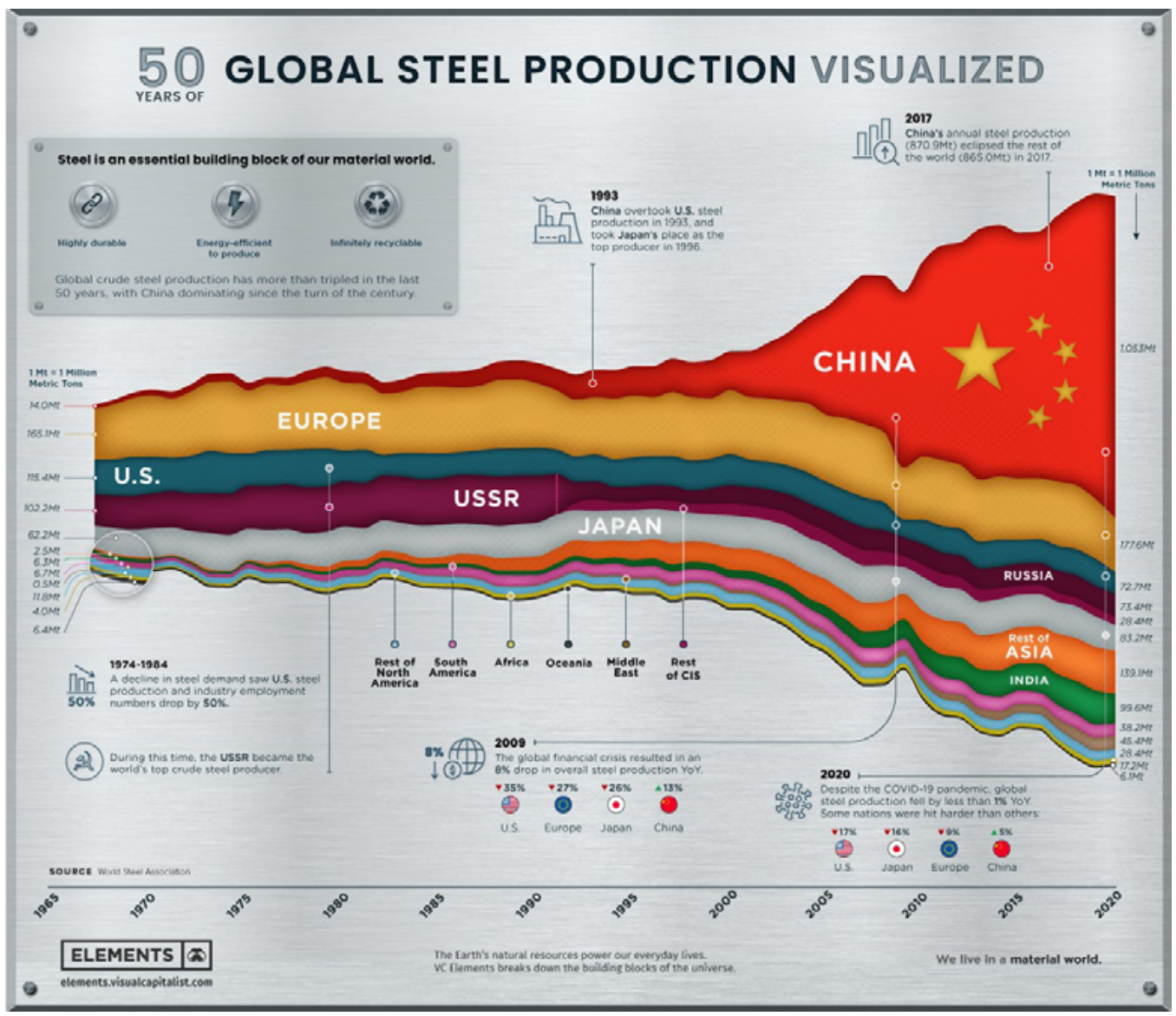

Figure 5: Global view of steel production capacity over the past 50 years ${ }^{14}$

leverage on transportation costs. A combination of these factors provided this country a significant structural advantage to achieve its industrialization quest which enabled a transition from an impoverished to flourishing manufacturing nation. ${ }^{7}$ However, at present, finding a solution to China's overcapacity is critical to the sustainability of the industry in the region and other nations have been pushing for decreased capacity. ${ }^{15}$ For example, Japan has been pushing for lower production volume out of China - especially as demand has peaked. In Korea's case, China's production capacity has forced steel manufacturers into business and financial restructuring due to slowed growth. In order to set themselves apart, companies like POSCO have refined their product line-up to offer more advanced, customized solutions that cannot be provided by high volume producing competitors. ${ }^{15}$

\subsection{South African steel industry challenge}

The South African enormous challenges facing beneficiation of its minerals are relatively substantial and are not challenges unknown to the industry and its government as summarised in Table 1 below. ${ }^{4,9,10}$ One major concern facing the South African downstream steel industry is the significant increase in imported steel products into South Africa. ${ }^{16}$ This puts pressure on local steel prices to be reduced, forcing many production companies to close

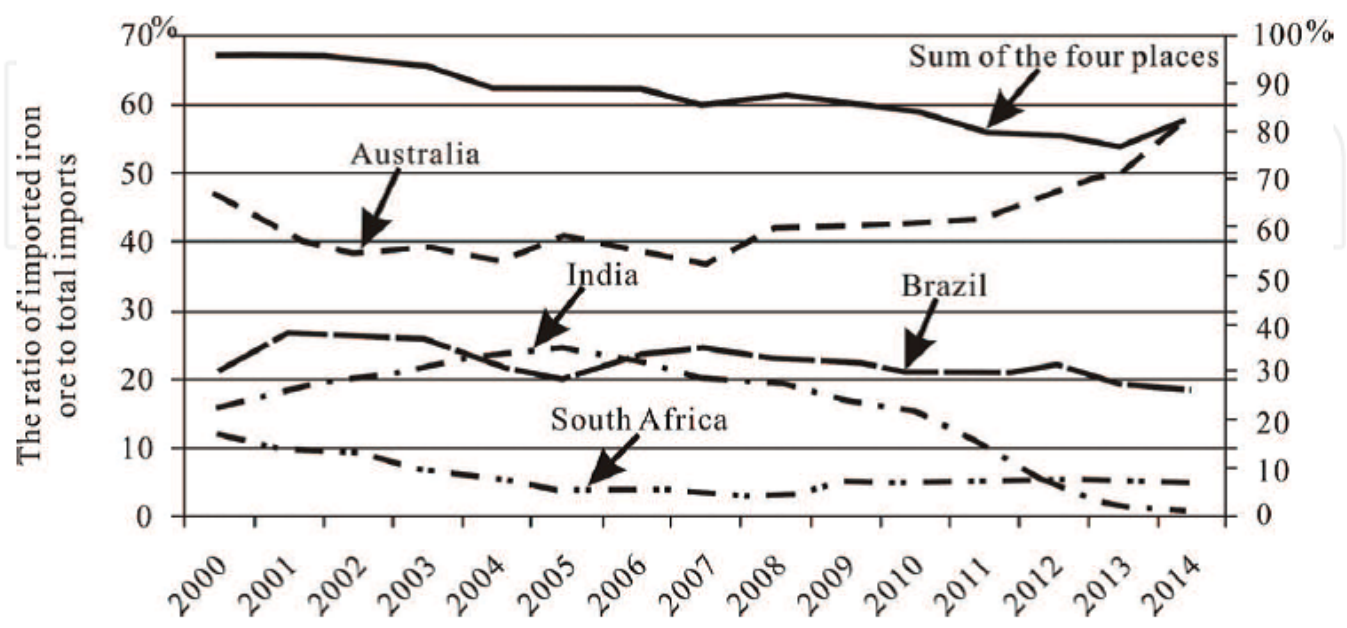

Figure 6: China's total imported iron ore in $2000-2014$ period $^{12}$ 
Table 1: SA Macroeconomic Challenges

\begin{tabular}{|c|c|c|}
\hline Issue & Government Solutions & Private Sector Solutions \\
\hline $\begin{array}{l}\text { Access to Raw Material } \\
\text { for Local Beneficiation }\end{array}$ & $\begin{array}{l}\text { Leverage the state's custodianship of minerals to facilitate } \\
\text { downstream beneficiation; } \\
\text { Amendments to the Mineral and Petroleum Resources Development } \\
\text { Act to strengthen beneficiation provisions; } \\
\text { Strengthen existing legislation to promote reliable and competitive } \\
\text { access to raw materials and; } \\
\text { Address import-parity pricing. }\end{array}$ & $\begin{array}{l}\text { Take advantage of the mineral } \\
\text { value proposition to expand local } \\
\text { demand for mineral ores } \\
\text { Comply with legislation }\end{array}$ \\
\hline Lack of Infrastructure & $\begin{array}{l}\text { Identify infrastructure needs for next } 20 \text { years } \\
\text { Ensure critical infrastructure programme correctly identifies } \\
\text { requirements for beneficiation } \\
\text { Leverage on the NGP and infrastructural supports }\end{array}$ & $\begin{array}{l}\text { Align production plans with } \\
\text { national programmes } \\
\text { Embrace energy efficiency } \\
\text { Explore co-generation prospects }\end{array}$ \\
\hline $\begin{array}{l}\text { Research and } \\
\text { Development }\end{array}$ & $\begin{array}{l}\text { Align beneficiation research and developments requirements to the } \\
\text { national ten year plan for science and technology }\end{array}$ & $\begin{array}{l}\text { Support and develop competitive } \\
\text { technologies }\end{array}$ \\
\hline $\begin{array}{l}\text { Skills Sought for } \\
\text { Expediting Local } \\
\text { Beneficiation }\end{array}$ & $\begin{array}{l}\text { Align the beneficiation skills pipeline to the National Skills } \\
\text { Development Strategy and the Sector Skills Plans } \\
\text { Promote skills development and partner with the relevant Sector } \\
\text { Education and Training Authorities (SETA) }\end{array}$ & $\begin{array}{l}\text { Investment in human capital } \\
\text { development } \\
\text { Enhance the National Skills } \\
\text { Development Strategy }\end{array}$ \\
\hline $\begin{array}{l}\text { Access to International } \\
\text { Markets for } \\
\text { Beneficiated Products }\end{array}$ & $\begin{array}{l}\text { Ensure future trade agreements adequately support the beneficiation } \\
\text { intent } \\
\text { Take advantage of the Comprehensive Strategic Partnership with } \\
\text { China to support investment in beneficiation in South Africa, and } \\
\text { access to markets in China }\end{array}$ & Leverage on trade agreements \\
\hline
\end{tabular}

down and thus decreasing local production capacity. Rising input costs are also a challenge in the downstream steel market.

The South African steel industry suffers from high steel production costs due to: ${ }^{11}$

- Aged plants and inefficiencies: lack of investment and maintenance;

- Energy: the high cost of electricity-electricity and gas price increases ( $>300 \%$ and $160 \%$ since 2007);

- Transport: the high cost to ship products to harbour - increasing rail tariffs ( $>100 \%$ increase since 2007 ), uncompetitive port charges and inefficiencies on domestic vs export lines (Sishen), AMSA additional road transportation costs for $2016 @$ R731m uncompetitive rail infrastructure and high road freight costs, and;

- Costs: $40 \%$ transport, electricity and wages dollar based inputs (iron-ore, coking coal).

The other challenges faced by the industry include: poor labour relations, lack of relevant skills, import parity pricing of steel, poor tariff systems and competition from China. The local industry suffers from lack of R\&D to produce newer local products that could give the market competitive advantage. Therefore there is a dire need for investment in R\&D and innovation.

The alarming rate at which the steel consumption is declining in SA, as shown in Figure 7, can only mean that some drastic interventions are urgently needed to avoid complete collapse of manufacturing industry. This could also suggest that SIP rollout are not as fast and sometimes not completely in sink with what the country can produce by itself for its own development and thus creating its own demand.

Limited capacity for beneficiation of ores while the rest is exported has its own consequences, some of which impacts heavily on downstream players (steel fabricators), as they start their operations on a back foot due to high input cost they must absorb as they do not benefit from ores being locally mined. This situation is further fuelled by the fact that by nature the iron and steel industry is a

\section{South African apparent steel consumption (000 t)}

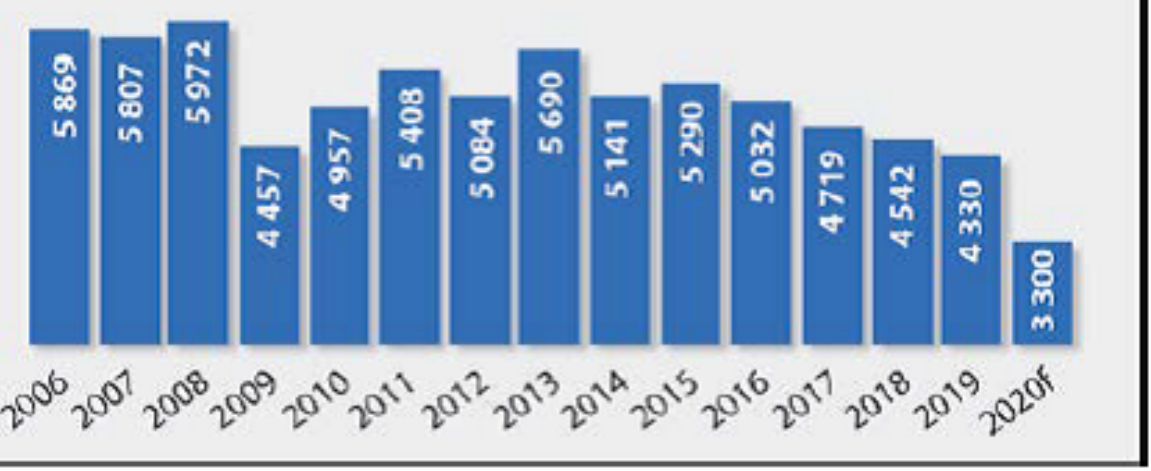

Source: Department of Trade, Industry and Competition $\mathrm{f}$ - forecast

Figure 7: South African apparent steel consumption 2006 - 2020 period $^{6}$ 
capital intensive environment, which acts as a barrier for new companies to enter the industry and hence having to tolerate and live with monopolistic arrogant behaviour of major role players. ${ }^{5,17}$ Only Foundry operations can avoid this high input cost as their key input material is steel scrap. However, their high input cost is on electricity as they most small to medium foundries make use of induction furnaces to melt scrap whereas the larger entities use much quicker electric arc furnaces. Lately, an additional energy constraint has been its availability.

The situation is further exacerbated by lack of capability and capacity to manufacture advanced high strength steels (AHSS) required for specialized applications. Most of higher education institutions have over the years lost interest to conduct R\&D in steels due to lack of industrial interest and support. Consequently, there remains inadequate number of capable human resource to support existing steel industries to become competitive which may drive down the import levels and drive development of new steels with enhanced properties demanded by several industries such as energy generation, pipelines, marine, mining, transportation, etc., with the possibility of unlocking the export opportunities in niche markets as a result of product sophistication..$^{18,19}$

\subsection{South African response to metals sector (including steel industry)}

In response to the above mentioned pertinent challenges in metals industry, the Department of Science and Innovation (DSI) has established an R\&D program called Advanced Materials Initiative (AMI). It is comprised of four networks cutting across key metals sectors, namely, the Light Materials Development Network (LMDN) hosted by CSIR, the Ferrous Materials Development Network (FMDN) and, the Precious Materials Development Network (PMDN) hosted by Mintek and the Nuclear Materials Development Network (NMDN) hosted by Necsa.

One of the AMI pillars relevant to the steel industry, herein discussed, is the Ferrous Materials Development Network (FMDN). The establishment of this network presents somewhat a unique opportunity to simultaneously add value to several minerals that South Africa possess in large quantities such as iron, chromium, manganese, vanadium, etc., while addressing key material challenges experienced by strategic sectors of the economy such as the transportation, energy and petrochemical industries. The FMDN R\&D programmes since inception in 2009 to date, has been running within a tripartite collaborative framework involving industry, academia and science councils embody this concept.

The broad objectives of the FMDN can thus be summarised as follows:

- Beneficiation of South Africa's ferrous resources. This will reduce the country's exposure to fluctuations in the world commodity prices and enable it to derive greater economic value from its mineral endowments;

- Improvement of the country's capability to produce high-end ferrous products, especially those that are needed by other critical sectors of the economy, such as petrochemical, energy generation, transportation, etc. This will have a snow-balling effect on the FMDN economic impact results;
- Generation of local know-how (innovation), including processes for which there could be potential royalties and/or development of new industries and associated job creation. This will ultimately catapult SA towards a knowledge-based economy with a realistic chance of being a net exporter of high-end products, by induction; this will reduce the country's dependence on imported products;

- Promotion of local and international collaboration in the field of ferrous metallurgy.

- Alleviate unemployment through mineral beneficiation, a key growth node for job creation.

- Promotion of a green economy through intelligent and innovative research.

- Human Capital Development through production of MSc and $\mathrm{PhDs}$ in science, engineering and technology, which will alleviate the shortage in scientific and technological qualifications and skills in these sectors and thereby ensuring the sustainability and the competitiveness of the local industry. This will also improve SA's attractiveness as an investment destination;

The industrial policy must become more supportive of and integrated into the iron and steel $R \& D$ agenda such that complementary industrialisation investments are being made (or will be made) in such a way that R\&D breakthroughs can be commercialised and brought to market such that improved competitiveness, job and value creating benefits are realised.

The research stack (especially in relation to industrial policy) is the holistic nature of the stack and its breadth of coverage. The stack includes R\&D into the required advanced processing and production techniques which will be required to enable $R \& D$ breakthroughs at the alloy development stage to be translated to real economy opportunities. The stack basically covers R\&D into iron and steel making capital equipment, forging techniques and equipment, rolling technologies and a range of other required complementary processes such as coatings. In addition, a Pilot Plant Testing is crucial for R\&D in the iron and steel industry where capital investments are so large.

Current RDI approach follows a strategic direction similar to that undertaken by global leaders in steel \& coatings R\&D, mostly in developed countries, which is built on the basis of the desire to integrate Computational Materials Science and Metallurgy in order to accelerate Materials Design and Discovery that responds to the existing industrial demand/challenges, in what is called ICME process. ${ }^{20-27}$ These $\mathrm{R} \& \mathrm{D}$ approaches are aimed at accelerating the development of advanced high strength steels (ADSS) and its effect in driving competitiveness. Laying a solid R\&D foundation enables SA to respond adequately and timeously to the industrial needs or challenges through Materials Design. Materials design is based on understanding key fundamental properties that will inform the choice of chemical compositions to be experimented on which holds promise to yield better or enhanced materials performance. These improved properties and other factors such as cost benefit, weight reduction, raw materials availability are crucial in creating competitive advantage.

The FMDN will be focused on the increase of ferrous metal consumption (reduced ferrous import consumption by 5\%) 
through the development of optimized casting and manufacturing technologies for the petrochemical, transport and mining industries providing:

- Advanced corrosion solutions for metal-based industry or materials for extreme environments (Petrochemical - SAPREF, PetroSA, Sasol, and Transportation - Railway and Marine)

\section{- Light weighting materials from advanced manufacturing and} processing such as durable steels used in energy generation plants and castings used in the rail, automotive and mining industries (Transnet, Shipbuilding, Automotive and Infrastructure)

The FMDN team has identified the above two (2) economicallyimportant research topics that need to be urgently bolstered if we are to safeguard and further improve metallurgical and technological skills-base. The selected topics are all of medium to long term value and will require numerous sub-projects during the implementation phase.

Steel is the most commonly used metallic alloy in the world, its dominance is likely to be the case, even 100 years from now. Due to its use almost everywhere, in cars, buses, ships, skyscrapers, power stations, oil rigs, magnets and thousands of domestic appliances, it is thus vital that innovative steel research continues, discovering even better compositions and enhanced processes that can unlock new applications. Such advanced materials with novel or improved structural and/or functional properties over the traditional materials are key part of the economy, providing the enabling technology for the 4th industrial revolution.

In the next 20 years, advances in manufacturing will likely be more networked, resulting in an increasingly automated and dataintensive manufacturing sector that will likely replace traditional manufacturing as we know it today. An advanced workforce, human capital development (HCD) will be needed to develop and maintain these advances in manufacturing. Advanced manufacturing produces goods that minimize use of resources while maintaining or improving cost and performance.

\subsection{Targeted sectors/markets}

The critical economic sectors to benefit from the FMDN programme are listed in Table 2, with reasons for intervention.

Table 2: Targeted Sectors/Markets

\begin{tabular}{|c|c|}
\hline Industry Sector & Intervention \\
\hline Mining & $\begin{array}{l}\text { Improved processes and grinding media } \\
\text { quality control testing }\end{array}$ \\
\hline $\begin{array}{l}\text { Petrochemical } \\
\text { and Energy }\end{array}$ & $\begin{array}{l}\text { Advice on materials used in extreme } \\
\text { environment, corrosion and hydrogen } \\
\text { induced cracking testing (HIC) }\end{array}$ \\
\hline $\begin{array}{l}\text { Manufacturing of } \\
\text { Mining Products }\end{array}$ & $\begin{array}{l}\text { Advice on casting and forging processes } \\
\text { and assisted in manufacturing of grinding } \\
\text { media (balls and liners) }\end{array}$ \\
\hline Automotive & $\begin{array}{l}\text { Assisting supplier of automotive industry } \\
\text { in approval for their manufactured } \\
\text { products }\end{array}$ \\
\hline Railway & $\begin{array}{l}\text { Specialised testing using AMI-FMDN } \\
\text { facilities, i.e. surface roughness } \\
\text { measurements, thermal analysis (STA), } \\
\text { metal dusting simulator, rolling contact } \\
\text { fatigue simulator }\end{array}$ \\
\hline
\end{tabular}

\subsection{Higher Education Institute (HEI) partners}

The academic partners currently participating in the human capital development aspect of this program are listed in Table 3. Since its inception, the FMDN programme has yielded the achievements summarized in Table 4.

\section{Industry partners}

The FMDN programme has signed a number of Non-Disclosure Agreements (NDA) with various industry partners currently participating in the research and innovation (RD\&I) aspect of this program as summarized below:

- SAPREF: to focus on corrosion issues, research in High Temperature Hydrogen Attack (HTHA) and composite materials;

- PetroSA: R\&D on corrosion issues (high temperature);

- Lekoa Technology: a SMME that produces mining components;

Table 3: Partnerships

\begin{tabular}{|c|c|c|}
\hline Name of Local Institution & Contribution/Area & Location \\
\hline University of Cape Town (UCT) & TEM Characterization & Local \\
\hline University of Limpopo (UL) & Materials Modelling & Local \\
\hline University of Venda (Univen) & Corrosion & Local \\
\hline University of Pretoria (UP) & Alloy Development and Welding & Local \\
\hline University of Zululand (UniZulu) & Machine Learning & Local \\
\hline Nelson Mandela University (NM & High Resolution Electron Microscope & Local \\
\hline University of the Witwatersrand (Wits) & Corrosion and Phase Diagram & Local \\
\hline $\begin{array}{l}\text { The Pennsylvania State University (Penn } \\
\text { State) }\end{array}$ & $\begin{array}{l}\text { Professional training programme, exchange of scientific material and } \\
\text { joint research }\end{array}$ & International \\
\hline Texas A\&M University (TAMU) & $\begin{array}{l}\text { Collaboration in research of materials for extreme environment and } \\
\text { Computational Programme }\end{array}$ & International \\
\hline University of New South Wales (UNSW) & $\begin{array}{l}\text { High temperature corrosion facilities, in particular carbon-induced } \\
\text { corrosion e.g. metal dusting and } \mathrm{CO}_{2} \text { corrosion }\end{array}$ & International \\
\hline $\begin{array}{l}\text { Central Metallurgical R\&D Institute, } \\
\text { (CMRDI) Cairo, Egypt }\end{array}$ & Collaboration in research on Production Technology of Ductile Iron & International \\
\hline
\end{tabular}


Table 4: RDI Achievements (5yrs)

\begin{tabular}{lccc}
\hline Status & PhDs & Masters & \# Publications \\
\hline Completed Studies & 8 & 8 & 3 Book Chapters \\
Ongoing Studies & 7 & 8 & 114 Peer Reviewed papers \\
\hline
\end{tabular}

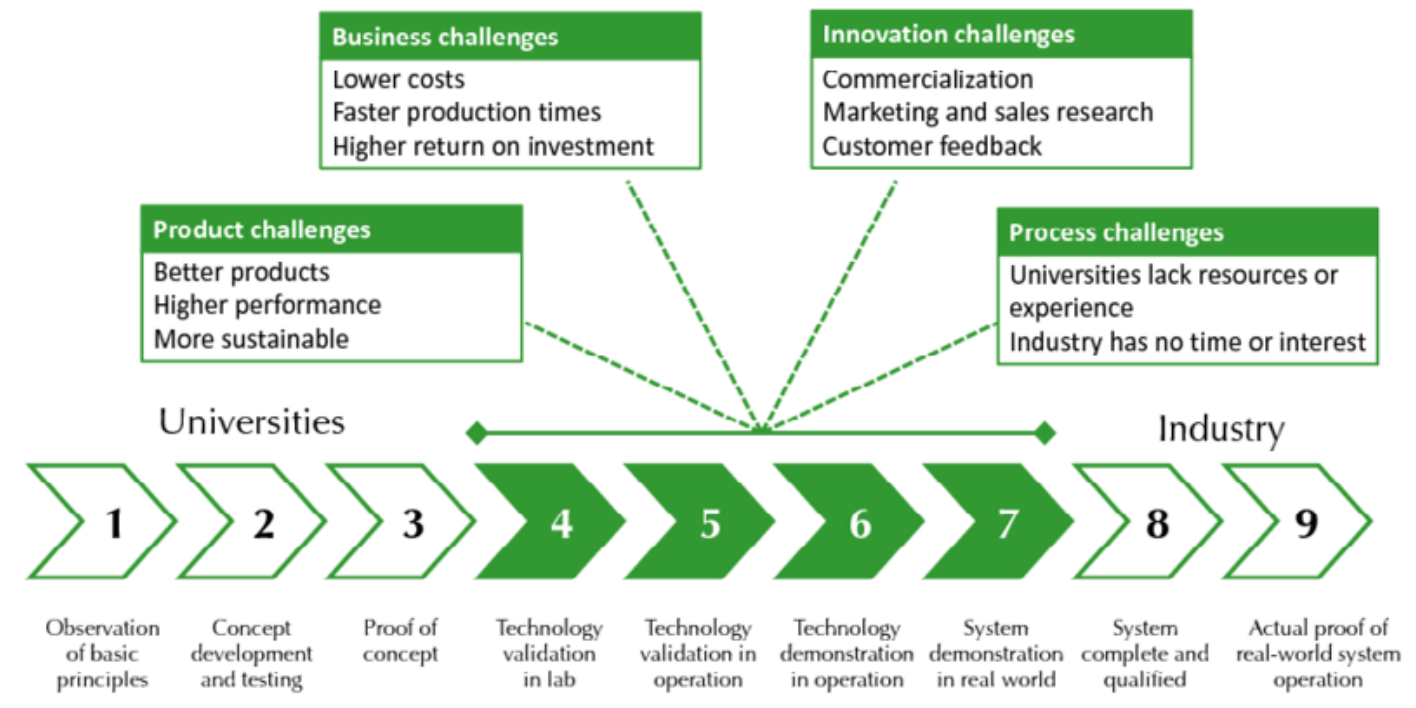

Figure 8: Technology Readiness Levels (TRLs)

- EVRAZ Holdings: to focus on Forging Technology for components to be used in mining sector;

- Scaw Zambia in Zambia: to offer a Foundry technology assistance package (mining components);

- Tema Steel and West African Forging (WAFOR) based in Ghana: to offer a technical intervention on their foundry, steel plant and optimisation of their forging process parameters - mining components and;

- Kingsmead Investment foundry in Botswana: to offer technical assistance and solutions on their permanent mould process used to produce high chromium balls.

The above mentioned partnerships are critical in ensuring participation and promotion of coordinated and interdependent R\&D activities within the FMDN platform cutting across the entire technology readiness levels (TRLs) shown in Figure 8, with emphasis on TRLs above 4. Learning from countries across the globe, these $\mathrm{R} \& \mathrm{D}$ links and connections are the back-bone of any RDI programmes that led to successful industrialization.

\section{Concluding remarks}

The main objective of the AMI-FMDN by the end of 2030 are to:

- Establish a materials research facility in the areas of improved processing technologies and advanced materials/alloys for the transport industry in line with the government localisation strategy (i.e. reduce imports) by employing Computational Materials Science (Modelling and Simulation) predictive tools.

- Establish a competency for corrosion investigation, control and monitoring to address the corrosion issues in the oil, gas, water, marine, mining and building industries in South Africa, i.e. a high and low temperature corrosion research focus in an effort to reduce the effects of corrosion on assets and the environment.

In the next ten years the FMDN focus is on increasing local ferrous metal consumption through the development of optimised systems and technologies for the transport, petrochemical and mining industries. This is in line with government's adopted developmental economic policy known as 'The New Growth Path' (NGP) which has identified six key sectors that must drive growth and job creation. The focus is to ensure greater local processing of South Africa's abundant natural resources, prioritising the mining value chain, with mineral beneficiation as one of the key economic activities that present the highest value proposition towards attainment of its objectives.

\section{Acknowledgements}

The authors acknowledge the financial support of the Department of Science and Innovation (DSI) for their financial support.

\section{Contributions of each author}

M Phasha: Conceptualisation, design of the work, analysis and interpretation, writing and editing of the manuscript. J Moema: Critical revision and edition of the manuscript, final approval of manuscript. J Papo: Critical reviewing and final approval of manuscript.

\section{References}

1. Piemonti, A., Conforti, A., Cominoli, L., Sorlini, S., Luciano, A. Plizzari, G., 2021. Use of Iron and Steel Slags in Concrete: State of the Art and Future Perspectives. Sustainability, 13, 556.

2. Council for Geoscience South Africa (CGSA). Selected active mines. http://www.geoscience.org.za/images/stories/selectedactivemines.gif 
3. South Africa's Iron Ore Industry Developments: 2004-2013, Directorate Mineral Economics, DMR.

4. Merchantec research, Industry Supply Analysis: Deliverable 1, 2014. Ferrous Metals Downstream Sector.

5. Trench, J.G., 2004. Role of the Chinese Steel Industry in the Economic Development of China and Australia's Contribution to the Industry as a Supplier of Raw Materials, PhD Thesis.

6. Creamer's Research Channel Africa, A Review of South African's steel sector, August 2020.

7. Kumba Iron Ore, The South African Iron and Steel Value Chain, 2011, www.kumba.co.za.

8. Kumba Iron Ore, Section 2 Creating A Growing and Sustainable Iron \& Steel Value Chain in SA, 2011, www.kumba.co.za.

9. Van Zyl, H.J., Bamt, W.G., Steenkamp, J.D., 2020. Identifying barriers to growth in mineral value chains. The Journal of the Southern African Institute of Mining and Metallurgy, 120, 149.

10. Merchantec research - Industry Challenges and Opportunities Analysis: Deliverable 3, Ferrous Metals Downstream Sector, 2015.

11. Presentation to the Joint Portfolio Committees on Trade and Industry \& Economic Development on the Steel Industry Interventions 23 August 2016, https://www.thedti.gov.za/parliament/2016/Steel Industry_Interventions.pdf

12. Tang, R., 2010. China's Steel Industry and Its Impact on the United States: Issues for Congress.

13. Holloway, J., Roberts, I., Rush, A., 2010. China's Steel Industry, Bulletin, December Quarter.

14. Conte, N., 2021. Visualizing 50 Years of Global Steel Production, https://www.visualcapitalist.com/visualizing-50-years-of-global-steelproduction/ Published on June 2.

15. Asian Steel Market: Barriers and Opportunities, https://newsroom. posco.com/en/remaining-competitive-in-the-asian-steel-market/, 2017.
16. Steel-Industry-Challenges-and-Opportunities, https://solidariteit.co.za/ wp-content/uploads, August 2015.

17. Kariga, R., Khumalo, L. Barriers to Entry, Exclusionary Strategies and Inclusive Growth, https://ryan-hawthorne.squarespace.com.

18. Deloitte, Overview of Steel and Iron Market, 2017.

19. Bodley, D., Bruch, S., Ralijaona, A., Sithole, R., 2013. Microeconomics of Competitiveness, HARVARD BUSINESS SCHOOL, The South African Iron Ore Cluster.

20. Wang, W.Y., Li, J., Liu, W., Liu, Z-K., 2019. Integrated computational materials engineering for advanced materials: A brief review. Computational Materials Science, 158, 42.

21. Wang, W.Y., et al, 2020. A brief review of data-driven ICME for intelligently discovering advanced structural metal materials: Insight into atomic and electronic building blocks. Journal of Materials Research, 35, 872.

22. Ye, Y.F., Wang, Q., Lu, J., Liu, C.T., Yang, Y., 2016. High-entropy alloy: challenges and prospects. Materials Today, 19, 349.

23. Diao, H.Y., Feng, R., Dahmen, K.A., Liaw, P.K., 2017. Fundamental deformation behaviour in high-entropy alloys: An overview. Current Opinion in Solid State and Materials Science, 21, 252.

24. Ikeda, Y., Grabowski, B., Körmann, F., 2019. Ab initio phase stabilities and mechanical properties of multicomponent alloys: A comprehensive review for high entropy alloys and compositionally complex alloys. Materials Characterization, 147, 464.

25. George, E.P., Raabe, D., Ritchie, R.O., 2019. High-entropy alloys. Nature Reviews, Materials, 4, 515.

26. Xiong, W., Olson, G.B., 2015. Integrated computational materials design for high-performance alloys. MRS Bulletin, 40, 1035.

27. Motaman, S.A.H., Kies, F., Köhnen, P., Létang, M., Lin, M., Molotnikov, A., Haase, C., 2020. Optical Design for Metal Additive Manufacturing: An Integrated Computational Materials Engineering (ICME) Approach. JOM, 72, 1092. 